\title{
Reflection on Innovation and Entrepreneurship of Business English Majors in Higher Vocational Colleges
}

\author{
Yong $\mathrm{Yu}^{1, \mathrm{a}}$, Li Liu ${ }^{2, \mathrm{~b}}$ and Guifeng Huang ${ }^{3, \mathrm{c}}$ \\ ${ }^{1}$ College of International Education, Hainan College of Economics and Business, Haikou, China, \\ 571127 \\ ${ }^{2}$ College of International Education, Hainan College of Economics and Business, Haikou, China, \\ 571127 \\ ${ }^{3}$ College of International Education, Hainan College of Economics and Business, Haikou, China, \\ 571127 \\ ayuyong163163@163.com, bhnllwqh@163.com, chgf0509@163.com
}

Keywords: Internet;Business English Majors;Innovation and entrepreneurship;Higher education; Business mode

\begin{abstract}
With the rapid development of the Internet, Business English majors in higher vocational colleges have become one of the main forces in start-up projects online. Many students in vocational colleges choose to start their own online businesses in line with current heated-topics, This thesis attempts to analyze the changes that the Internet has brought to higher education, business modes along with the advantages of starting a business on the Internet, and finally puts forward tips for Business English Majors on starting a business on the Internet.
\end{abstract}

\section{Changes in Higher Education in Internet -plus Environment}

Internet- plus mainly refers to a mode of internet education which is combined with traditional industry methods, but it is not a simple combination, rather, it is a new business mode that is based on the internet through the combination of innovation and traditional industries. It is the combination of Internet- plus and traditional industries that brings about electronic methods of payment such as the Alipay, online bank, Taobao and Didi App Call and online as well as offline teaching methods. Each of these have brought to people a brand new life style. With the rapid development of the Chinese economy, Internet- plus has made its place in all works of life. Universities and colleges have made great efforts to push forward the innovation and entrepreneurship of the Internet- plus environment and promote the cultivation of innovative talents.

\subsection{The Change of Education Mode Made by Internet- plus}

With the popularity and development of the Internet, great convenience has been brought to students. This is said to be a blessing for them in the 21st century. Teachers have evolved from teaching via blackboard to teaching via multimedia. This change has set teachers and students free both spiritually and physically and thus greatly increased the efficiency of teaching and learning overall. Up until now, online teaching has become popular with families and campuses far and wide. Through use of the internet, teachers can establish courses on network so that students can listen to their lectures whenever and wherever they are, thus improving the quality of education. On the Internet, students can listen to the lectures given by entrepreneurs on websites whether at home or abroad and they can complete the corresponding study tasks and homework online through Mooc to help them quickly master what they have learnt online that same day. When students have finished their online homework, teachers can check and mark it. By taking advantage of the internet, the aim to share resources among universities is achieved. It is believed that innovation and 
entrepreneurship courses are sure to improve through the development of the Internet-plus platform.

\subsection{Changes of the Business Mode Made by the Internet}

The Internet has changed the traditional business mode to a great extent, from shopping in traditional real shops to shopping online. At present, people buy and sell products through the platform of the Internet. In the past, students needed to set up a real shop and assigned specific positions if they wanted to start a business. But now, they can set up online platforms through the Internet to make deals. On the virtual platform, students can accumulate experience too. College students should take advantage of the developing mode of the internet and college teachers should offer guidance. Only in this way can innovation and entrepreneurship on the Internet win success.

Business English Majors in higher vocational colleges have new ideas and new ways of thinking about start-up online, as the Internet has greatly changed their way of living. Hence, start-up online has become a better way for students to start a business.

\section{Advantages of Initiative Start-up by College Students in Higher Vocational Colleges in Internet- plus Environments}

\subsection{Low Cost}

College students lack in both experience and the fundamental foundation needed to support a real-shop business under the traditional mode. In the 21st century, however, with the abundance of online resources, the internet is quite a practical method for start-up for college students. Start-up online requires no rent payment as a real shop often does, rather, it exists as a virtual shop. Without the need of large amount of capital and the pressure of stocking, the expense can be spared and rapid circulation of capital can be promoted as well.

\subsection{New Marketing Mode}

There exist various resources on the Internet, allowing college students to do online marketing through regular channels, such as utilizing search engines, big portal websites, video production and sharing, communication via email, online live broadcast, and telecommunication tools. All of these provide marketing methods for online start-up, expand marketing methods, spreading informative resources and effectively lowering the cost and expense of marketing.

\subsection{Rapid and Effective Advertising Method}

Nowadays, Mobike has become the most popular means of transportation and has spread across all big cities in China. The idea of establishing Mobike was to encourage people to travel by bikes, so as to reduce Carbon dioxide emissions in order to create a cleaner and neater environment. The founder and president of Mobike, $\mathrm{Hu}$ Weiwei , is a newly-graduated college student. She established Mobike following the shared idea of Didi App Call. The success of Mobike has greatly attributed to the rapid development of China Mobile Internet and the fast dissemination of information online, and has become fashionable in Chinese big cities. Mobike has gained favor from most citizens and attracts young people to travel by bikes.

Hu Weiwei, the founder, not only established Mobike but also brought forth great technical innovation. The difference between Mobike bikes and traditional bikes is that Mobike's bikes don't breakdown or wear out over time resulting in things such as chains falling off. Mobike bike's tires are non-pneumatic and each bike has its own code with GPS system , which efficiently avoids loss and damage of the bikes. Mobike has become the third largest public means of transportation, the other two being bus and metro. With the spread of this shared and developed idea, other similar platforms have came into being such as umbrella-rental, car-rental and shared parking lots which have also entered the market. College students can take advantage of the Internet and fully make use of it to start businesses. 


\section{Advantages of Start-up by Business English Majors in Higher Vocational Colleges in Internet Environment}

The training objectives of business English Majors in Higher Vocational Colleges are based on China's international trade industry and servicing enterprises, to cultivate practice-based , and interdisciplinary foreign language talents with good professional ethics and the basic knowledge and theory of international trade, having strong import and export operation skills and solid business processing capabilities, being able to use English as a working language to participate in international business activities and engaged in the front-line work of international trade.

With the rapid development of China's foreign trade economy and the promotion of One Belt And One Road construction, the trade and economic exchanges between China and the rest of the world are expanding. The Internet environment has made this economic interaction more profound and faster. This provides business English majors in higher vocational colleges with excellent entrepreneurial opportunities, especially in cross-border E-commerce, for as we all know, cross-border E-commerce is not only a platform application, but also a brand new business model and industrial innovation based on Internet-plus. It allows the flow of goods and involves the exchange of languages and cultures as well. In the cross-border E-commerce mode, only by mastering foreign languages, understanding foreign cultures and having intercultural communication can the transactions be promoted and completed smoothly. Business English majors have the basic ability and conditions to obtain foreign information, they understand the cultural differences between China and foreign countries, their knowledge of foreign languages and their corresponding cross-cultural knowledge have given them a unique advantage in cross-border E-commerce, especially on the level of cultural creativity. They are able to integrate humanistic values and cultural creative elements into products and services, making them unique and iconic, thus improving their competitiveness.

\section{Countermeasures for Business English Majors in Higher Vocational Colleges in the Internet Environment}

Firstly, business English majors in higher vocational colleges should grasp the characteristics of the Internet, define their own entrepreneurial goals and entrepreneurial orientation, fully understand the market demand and conduct market research, make great efforts to broaden marketing channels and marketing methods, highlight their own entrepreneurial features/abilities, make good use of their entrepreneurial advantages so as to establish good reputations and gain credit. Furthermore, they should conduct a comprehensive assessment of the sales, profits and losses of entrepreneurial projects, raise awareness of possible risks in starting and undertaking and ensure the feasibility of a startup project. Finally, they should establish good interpersonal relationships and team spirit in order to lay a solid foundation for innovation and entrepreneurship.

Business English majors need to study marketing, E-commerce, computer science, financial management, economics and other relevant courses. The knowledge reserves of these specialized courses are conducive to their innovation and entrepreneurship within the Internet environment. Moreover, they should master a series of operation modes of Internet platforms such as marketing strategy, transaction mode, processes of transaction and after-sales services.

\section{Concluding Remarks}

Nowadays, Internet- plus has become increasingly important in people's daily lives. It affects people's lifestyle and methods of travel. Business English Majors in higher vocational colleges should make good use of their own advantages, seize the opportunities in the process of Internet entrepreneurship, overcome setbacks of Internet entrepreneurship, and strive to achieve their goals of entrepreneurship.

The Internet era is here, and we hope that business English majors in higher vocational colleges 
can grasp the business model and opportunities under the E-commerce era, combine their innovation consciousness with the Internet- plus background, improve their ability of innovation and entrepreneurship, create a new world of their own and promote the rapid development of innovation and entrepreneurship

\section{References}

[1] Jun Wu, Lanlan Wu. Difficulties and Countermeasures of Innovation and Entrepreneurship Education in Colleges and Universities under the New Situation[J], Innovation and Entrepreneurship Education, 2017(01)

[2] Yuan Li. Practical Teaching Reform of Mechanical Design Major from the Perspective of Ability Training of Innovation and Entrepreneurship [J], China Metallurgical Education, 2017(01)

[3] Liping Yang, Wei Wang, Huangrong Zeng. Design of Educational Network Platform for College Students Based on SSH Architecture[J], Software Guide, 2011(06)

[4] Wen Quan, The Research Methods of Entrepreneurship Education for College Students under the Background of Internet Plus[J], Journal of Guangxi Youth Cadre Institute, 2017(01)

[5] Haisheng Chen. The Exploration of Entrepreurship Models of Cross-border E-commerce for Foreign Language Majors in the "Internet Plus" Era[ J]. Journal of Chifeng University(Natural Science Edition), 2016(08) 